\title{
Genetic and Population Studies of Quantitative Levels of Adenosine Triphosphate in Human Erythrocytes
}

\author{
George J. Brewer ${ }^{1}$
}

Received 5 Dec. 66-Final 30 Jan. 67

The mean content of ATP in red cells of American Negroes is significantly less than the mean level in American Caucasians. This is compatible with the hypothesis that the quantitative level of ATP in red cells may be involved in selective processes related to falciparum malaria. There is no evidence of a sex effect on levels of ATP in either population. Family studies conducted in both populations indicate that the quantitative level of red cell ATP is at least partially inherited. Studies of a number of biochemical characteristics of red cells have been conducted in an effort to elucidate the mechanism of genetic and biochemical control of quantitative levels of erythrocytic ATP. These studies have been negative. Although other studies have demonstrated that thalassemia trait influences the level of red cell $A T P$, the presence of sickle cell trait or G-6-PD deficiency, the other two systems postulated to be involved in malaria protection, did not result in significant differences in mean red cell ATP content.

\section{INTRODUCTION}

Preliminary studies in our laboratory have indicated that the mean level of erythrocytic adenosine triphosphate (ATP) in American Negroes is significantly lower than that of American Caucasians (Brewer, 1965b). This observation led to studies suggesting that relatively low levels of red cell ATP in the Negro may be protective against falciparum malaria (Brewer and Powell, 1965). It has also been found that heterozygotes for the beta thalassemia gene have significantly lower levels of erythrocytic ATP than normal individuals (Loos et al., 1965; Brewer et al,, in preparation). It seems possible that the postulated protective effect of thalassemia against malaria may result from an effect of the thalassemia gene on levels of red cell ATP. The possibility of an important role for ATP in selective processes related to malaria makes

\footnotetext{
The work reported in this paper was supported in part by the Research and Development Command, Office of the Surgeon General, Department of the Army, under contract DA-49-193-MD-2855 with the Department of Medicine, University of Michigan. With respect to this support, it is contribution number 167 from the Army Research Program on Malaria. The work was also supported in part by USPHS grant AM 09381 and USPHS Career Development Award 1-K3-AM 7959.

1 Departments of Medicine (Simpson Memorial Institute) and Human Genetics, University of Michigan Medical School, Ann Arbor.
} 
it important to study the inheritance of quantitative levels of erythrocytic ATP and to investigate the possible influence of other erythrocyte enzymes on ATP content in hopes of elucidating mechanisms of genetic control.

In this paper we report:

1. The results of an expanded population study of the content of ATP in erythrocytes in a sample of American Negroes and Caucasians.

2. The results of family studies of erythrocytic ATP content.

3. The results of studies correlating various biochemical features of erythrocytes with levels of ATP.

\section{METHODS}

Subjects for the random population survey came primarily from two sources. Most male subjects were inmate volunteers of the Southern Michigan State Prison at Jackson, Michigan. The female subjects and the remainder of the male subjects were individuals who had blood drawn at the University of Michigan University Hospital Outpatient Laboratory. The latter group were individuals who were having preemployment physical examinations or who were being seen in the Outpatient Clinic for a variety of minor, nonhematologic disorders. Family studies were performed on the families of a subsample of the clinic group and on the families of laboratory personnel. Individuals with G-6-PD deficiency or sickle cell trait were not excluded except in the studies of correlation between biochemical parameters of erythrocytes and ATP levels.

Adenosine triphosphate of red cells was measured by a modification of the method of Kornberg (1950) as previously described (Brewer and Powell, 1966). Activities of glucose-6-phosphate dehydrogenase (G-6-PD) and 6-phosphogluconate dehydrogenase in hemolysates were measured by the method of Glock and McLean (1953) as reported by Zinkham and Lenhard (1959). Pyruvic kinase activity of hemolysates was assayed by the method of Tanaka et al. (1962) as modified by Powell and DeGowin (1965). Glutathione reductase activity of hemolysates was assayed by the method of Long and Carson (1961). Hexokinase activity in hemolysates was measured as previously reported (Brewer et al., 1964). Inorganic phosphate in serum was measured by the method of Fiske and Subbarow (1925). Electrophoretic typing of red cells for acid phosphatase, phosphoglucomutase, and adenylate kinase was carried out by the methods of Hopkinson et al. (1964), Spencer et al. (1964), and Fildes and Harris (1966), respectively. Screening of Negro populations for G-6-PD deficiency was carried out with the methemoglobin reduction test (Brewer et al., 1960 and 1962). Hemoglobin electrophoretic types of some Negro subjects were determined during starch gel electrophoresis carried out for enzyme studies.

\section{RESULTS \\ Population Studies}

In Fig. 1 the level of erythrocytic ATP in unrelated adult Negro males is compared to the level in an equal number of adult Caucasian males. All 402 of these subjects 
were inmates of the Jackson prison, and hence were living under identical environmental conditions. The mean of the values of the Negro subjects is significantly less than that of the Caucasians $(P<0.001) .{ }^{2}$ Similar results were obtained in a comparison of 104

Fig. 1. Comparison of frequency distributions of 201 adult Negro males and 201 adult Caucasian males, all of whom were inmates of Southern Michigan Prison at Jackson, Michigan.

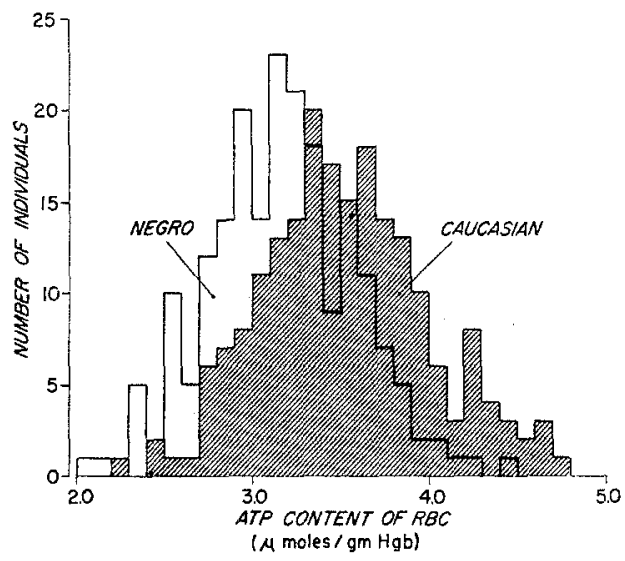

Fig. 2. Comparison of frequency distributions of 104 adult Negro females and the first 104 adult Caucasian females studied.

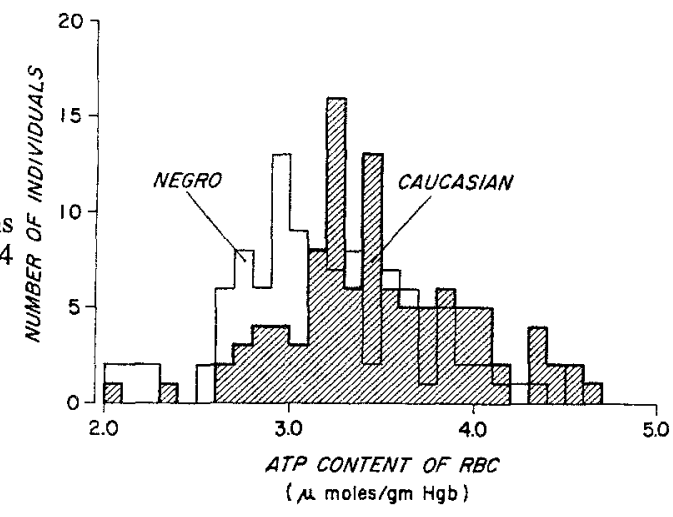

adult Negro females with 104 adult Caucasian females (Fig. 2); the means of these distributions also differ significantly $(P<0.001)$. A summary of the total data collected to date in the two populations and statistical evaluation are shown in Table I. There is no evidence of a sex effect on levels of ATP (Table I).

\section{Family Studies}

Studies of the inheritance of quantitative levels of ATP in red cells have been conducted in both Negro and Caucasian families. Analyses of covariance (Tables II and ${ }^{2}$ The differences of the means were tested for statistical significance by Students " $t$ " using the tables
for the $t$ distribution presented by Fisher (1958). 
III) demonstrate that after age adjustment, ${ }^{3}$ between sibship variation is significantly greater than within sibship variation. Significant differences among family means, adjusted for age, indicate that either inheritance or environmental influences, or both, influence levels of red cell ATP in both populations.

One method for at least partially evaluating the role of environmental influence is to determine the correlation coefficient between spouses (Table IV). The absence of positive correlation between spouses suggests that environmental influences in the home during adult life do not play an important role in influencing levels of red cell ATP.

Table I

\begin{tabular}{llccccc}
\hline Sex & Race & $\begin{array}{c}\text { Number of } \\
\text { subjects }^{a}\end{array}$ & $\begin{array}{c}\text { Mean } \\
\text { ATP }^{b}\end{array}$ & S.D. & $\boldsymbol{t}^{d}$ & $P$ \\
\hline M & Negro & 319 & 3.16 & 0.42 & 7.48 & $<0.001$ \\
M & Caucasian & 247 & 3.47 & 0.47 & & \\
F & Negro & 104 & 3.19 & 0.52 & 4.24 & $<0.001$ \\
F & Caucasian & 155 & 3.48 & 0.52 & & \\
M & Negro & 319 & 3.16 & 0.42 & 0.20 & $<0.9$ \\
F & Negro & 104 & 3.19 & 0.52 & & \\
M & Caucasian & 247 & 3.47 & 0.47 & 0.20 & $<0.9$ \\
F & Caucasian & 155 & 3.48 & 0.52 & & \\
M \& F & Negro & 423 & 3.17 & 0.44 & 9.01 & $<0.001$ \\
M \& F & Caucasian & 402 & 3.47 & 0.49 & & \\
\hline
\end{tabular}

${ }^{a}$ All the subjects were adults.

${ }^{b}$ Expressed in micromoles of ATP per gram of hemoglobin.

c One standard deviation.

d $t$ test of Fisher (1958).

\section{Studies of the Correlation Between Various Biochemical Parameters of Erythrocytes and Variation in Erythrocytic ATP}

Serum Inorganic Phosphorus Levels and Activities of Glutathione Reductase, $G-6-P D$ and 6-PGD. It has been observed that the increased level of inorganic phosphorus in the serum of uremic patients results in an elevation of red cell ATP levels

${ }^{3}$ Although not presented in this paper, preliminary evidence of an age effect on erythrocyte ATP from birth until age 21 (Gall, Sing, and Brewer, unpublished) suggested that family differences should be adjusted for age. The analysis of covariance (Steel and Torrie, 1960) of ATP adjusted for age is given in Table II for 17 Negro families and in Table III for 9 Caucasian families. The mathematical model which is considered may be written

$$
Y_{i j}=\mu+f_{i}+b x_{i j}+e_{i j}
$$

where $Y_{i j}$ is the ATP level of the $j$ th individual of the $i$ th family, $\mu$ is the general mean, $f_{i}$ is the fixed genetic effect of the $i$ th family, $b$ is the linear regression of ATP on age, $x_{i j}$ is the deviation $\left(x_{i j}-\bar{x}\right)$ of the age of the $j$ th individual of the $i$ th family from the average age, and $e_{i j}$ is the random error effect associated with the $j$ th observation in the $i$ th family. A reduction of $22 \%$ and $15 \%$ in the error variance among Caucasian and Negro individuals, respectively, was realized by employing the covariance analysis. The $\mathrm{F}$ ratio was used to detect significant differences among family means adjusted for age. 
Table II. Analysis of Covariance-Negro Families

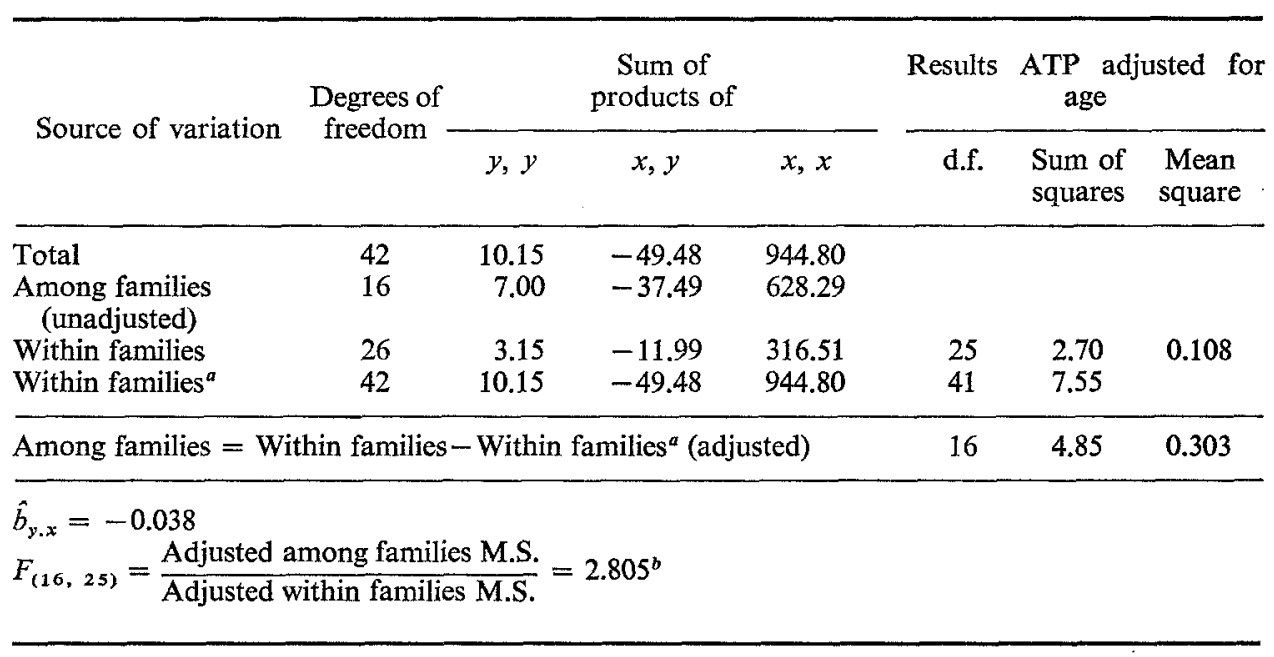

${ }^{a}$ Error associated with the model, $Y_{j}=\mu+b^{\prime} x_{j}+e^{\prime}{ }_{j}$ which ignores family effects.

${ }^{b}$ Significant at the 0.025 probability level.

Table III. Analysis of Covariance-Caucasian Families

\begin{tabular}{|c|c|c|c|c|c|c|c|}
\hline \multirow{2}{*}{ Source of variation } & \multirow{2}{*}{$\begin{array}{l}\text { Degrees of } \\
\text { freedom }\end{array}$} & \multicolumn{3}{|c|}{$\begin{array}{l}\text { Sum of } \\
\text { products of }\end{array}$} & \multirow{2}{*}{$\begin{array}{c}\text { Results } \\
\text { d.f. }\end{array}$} & \multicolumn{2}{|c|}{$\begin{array}{l}\text { ATP adjusted for } \\
\text { age }\end{array}$} \\
\hline & & $y, y$ & $x, y$ & $x, x$ & & $\begin{array}{l}\text { Sum of } \\
\text { squares }\end{array}$ & $\begin{array}{l}\text { Mean } \\
\text { square }\end{array}$ \\
\hline $\begin{array}{l}\text { Total } \\
\text { Among families } \\
\text { (unadjusted) }\end{array}$ & $\begin{array}{r}26 \\
8\end{array}$ & $\begin{array}{l}6.31 \\
3.11\end{array}$ & $\begin{array}{r}-24.15 \\
-8.56\end{array}$ & $\begin{array}{r}1316.30 \\
965.86\end{array}$ & & & \\
\hline $\begin{array}{l}\text { Within families } \\
\text { Within families }\end{array}$ & $\begin{array}{l}18 \\
26\end{array}$ & $\begin{array}{l}3.20 \\
6.31\end{array}$ & $\begin{array}{l}-15.59 \\
-24.15\end{array}$ & $\begin{array}{r}350.45 \\
1316.30\end{array}$ & $\begin{array}{l}17 \\
25\end{array}$ & $\begin{array}{l}2.51 \\
5.87\end{array}$ & 0.147 \\
\hline \multicolumn{5}{|c|}{ Among families $=$ Within families - Within families ${ }^{a}$ (adjusted) } & 8 & 3.36 & 0.420 \\
\hline \multicolumn{8}{|c|}{$\begin{array}{l}\hat{b}_{y . x}=-0.044 \\
F_{(8,17)}=\frac{\text { Adjusted among family M.S. }}{\text { Adjusted within family M.S. }}=2.875^{b}\end{array}$} \\
\hline
\end{tabular}

${ }^{a}$ Error associated with the model, $Y_{j}=\mu+b^{\prime} x_{j}+e^{\prime}{ }_{j}$ which ignores family effects.

${ }^{b}$ Significant at the 0.05 probability level.

Table IV. Coefficients of Correlation Between Spouses in Levels of Erythrocytic ATP

\begin{tabular}{lcrc}
\hline & $r$ & $N$ & $P$ \\
\hline Negro couples & -0.062 & 14 & $>0.1$ \\
Caucasian couples & -0.254 & 7 & $>0.1$ \\
\hline
\end{tabular}


(Hurt and Chanutin, 1964). The role of serum inorganic phosphorus in the regulation of red cell ATP levels under physiological circumstances was evaluated in 44 normal Negro males (Fig. 3). The correlation coefficient between serum inorganic phosphorus and red cell ATP $(r=+0.168, N=44)$ was not significantly different from zero.
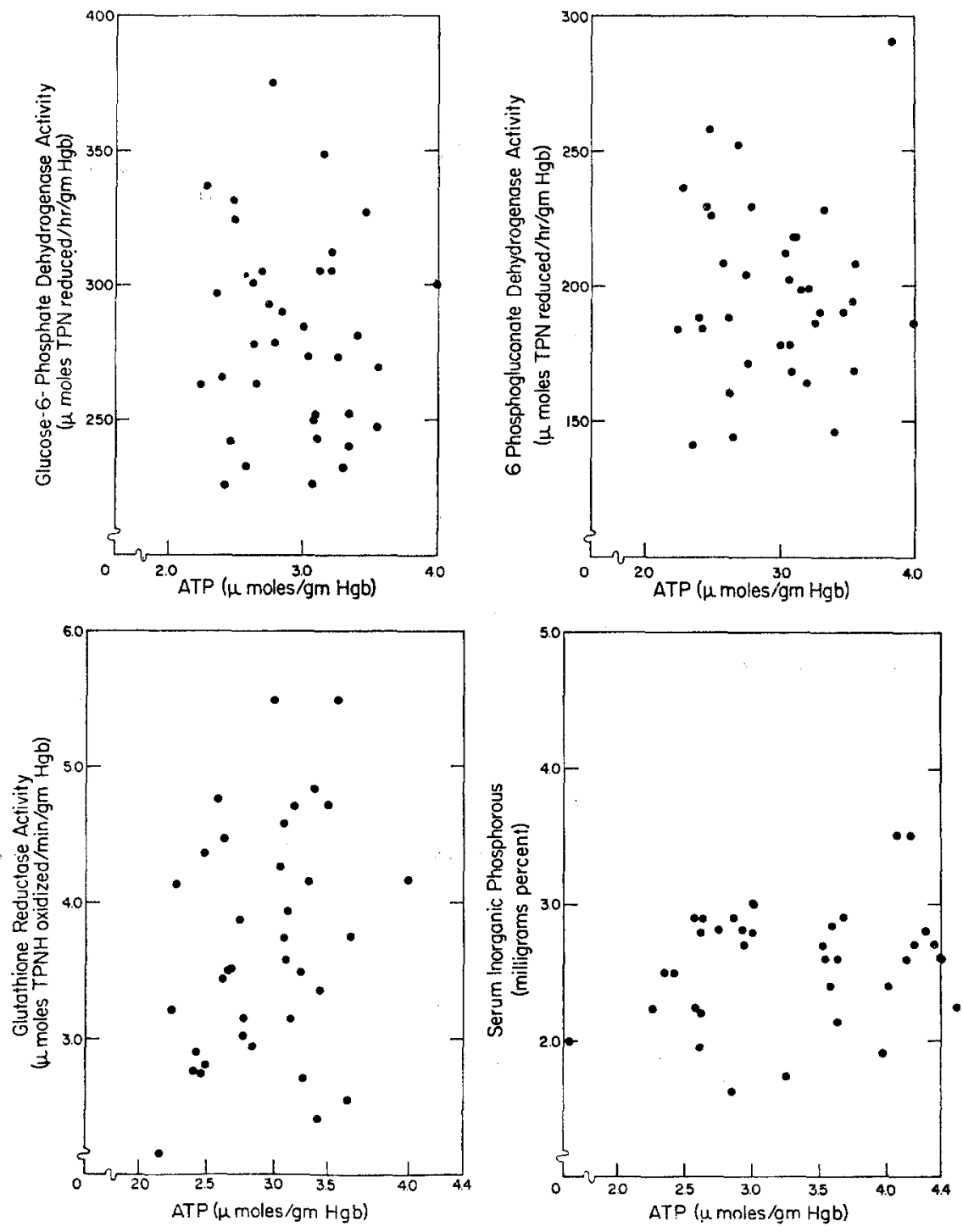

Fig. 3. Correlation diagrams showing the lack of significant correlation between erythrocytic ATP and serum inorganic phosphorus, and between ATP and the activities of three red cell enzymes in male adult Negro subjects.

Data correlating the activity of each of three erythrocytic enzymes with ATP content of red cells of Negro males are also shown in Fig. 3. Correlation coefficients were not significantly different from zero. 
Activity of Pyruvic Kinase in Red Cells. One of the steps in the glycolytic pathway of carbohydrate metabolism in which ATP is regenerated is the reaction catalyzed by pyruvic kinase. The role of variation in activity of pyruvic kinase in regulating ATP levels of erythrocytes was evaluated in 35 Negro and 34 Caucasian individuals (Fig. 4). The correlation coefficients between hemolysate pyruvic kinase activity and ATP levels of red cells in Negroes and Caucasians individually, and in the pooled data, were not significantly different from zero.

Fig. 4. Correlation diagram showing the lack of significant correlation between erythrocytic ATP and hemolysate pyruvic kinase activity in 35 adult Negro and 34 adult Caucasian individuals.
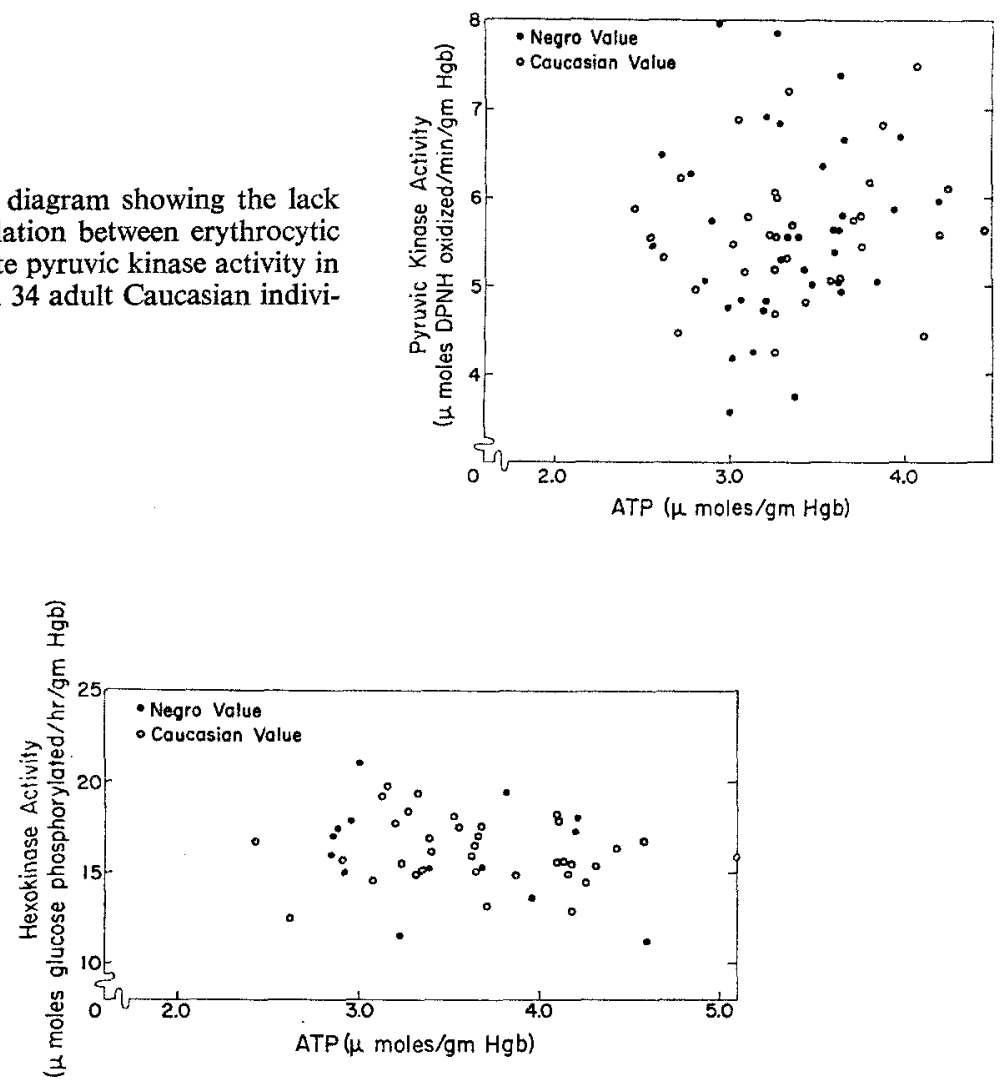

Fig. 5. Correlation diagram showing the lack of significant correlation between erythrocytic ATP and hemolysate hexokinase activity in 14 adult Negro and 35 adult Caucasian subjects.

Activity of Hexokinase in Red Cells. Hexokinase catalyzes the initial phosphorylation of glucose, and may be rate-limiting in the human erythrocyte. The role of variation in hexokinase activity in regulating ATP levels was evaluated in 35 Caucasian and 14 Negro subjects (Fig. 5). The correlation coefficients for the Negro, the Caucasian, and the pooled data did not differ significantly from zero.

Acid Phosphatase, Phosphoglucomutase, and Adenylate Kinase Electrophoretic Types in Red Cells. The mean content and standard deviation of ATP in red cells of 
Negro male subjects with various electrophoretic types of acid phosphatase, phosphoglucomutase, and adenylate kinase are shown in Table V. Significant effects of electrophoretic type on erythrocytic ATP levels were not detected ( $t$ test), although the sample size in the case of adenylate kinase was quite small.

Table V

A. Comparison of ATP Levels in Erythrocytes with Various Acid Phosphatase Electrophoretic Phenotypes (Adult Negro Population Only).

\begin{tabular}{ccc}
\hline $\begin{array}{c}\text { Acid phosphatase } \\
\text { phenotype }\end{array}$ & Number & $\begin{array}{c}\text { Mean level of } \\
\text { ATP } \pm \text { One S.D. }\end{array}$ \\
\hline A & 10 & $3.24 \pm 0.31$ \\
BA & 39 & $3.23 \pm 0.48$ \\
B & 117 & $3.12 \pm 0.38$ \\
CB & 2 & 3.25 \\
\hline
\end{tabular}

B. Comparison of ATP Levels in Erythrocyte with Various Phosphoglucomutase Electrophoretic Phenotypes (Adult Negro Population Only).

\begin{tabular}{ccc}
\hline $\begin{array}{c}\text { Phosphogluco- } \\
\text { mutase } \\
\text { phenotype }\end{array}$ & Number & $\begin{array}{c}\text { Mean level of } \\
\text { ATP } \pm \text { One S.D. }\end{array}$ \\
\hline 1 & 24 & $3.40 \pm 0.66$ \\
$2-1$ & 15 & $3.13 \pm 0.61$ \\
2 & 1 & 3.38 \\
\hline
\end{tabular}

C. Comparison of ATP Levels in Erythrocytes with Various Adenylate Kinase Electrophoretic Phenotypes (Adult Caucasian Population Only).

\begin{tabular}{ccc}
\hline $\begin{array}{c}\text { Adenylate kinase } \\
\text { phenotype }\end{array}$ & Number & $\begin{array}{c}\text { Mean level of } \\
\text { ATP } \pm \text { One S.D. }\end{array}$ \\
\hline 1 & 15 & $3.46 \pm 0.28$ \\
$2-1$ & 5 & $3.24 \pm 0.36$ \\
\hline
\end{tabular}

Sickle Cell Trait and G-6-PD Deficiency. The mean content of ATP in the red cells of 19 male Negroes with sickle cell trait (3.147 $\mu$ moles/g Hb) did not differ significantly from the mean of non-sickling Negro males $(3.158 \mu$ moles $)$. The mean content of ATP in erythrocytes of 35 G-6-PD deficient Negro males ( $3.284 \mu$ moles) did not differ significantly $(0.1>p>0.05)$ from that of nondeficient Negro males (3.143 $\mu$ moles), confirming our earlier report on a smaller number of subjects (Brewer and Powell, 1966).

\section{DISCUSSION}

It is clear that although there is considerable overlap in the distributions, the mean level of erythrocytic ATP in Negroes is significantly less than the mean level in 
Caucasians. Such biochemical differences between red cells of Negroes and Caucasians may arise as a result of selective effects of falciparum malaria, since the gene pool of the American Negro is recently derived from an African stock extensively exposed to malaria. The hypothesis that relatively low levels of ATP in red cells is protective against malaria has been supported by preliminary studies with human volunteers (Brewer and Powell, 1965). Further, it appears that the role of quantitative levels of ATP in the severity of the malarial attack may offer an explanation for the hypothesized protective effect of thalassemia against malaria. It was first observed by Loos et al. (1965) in the Netherlands and confirmed in Sardinia (Brewer et al., in preparation) that individuals heterozygous for beta thalassemia have lower mean levels of ATP than nonthalassemics. Thus, beta thalassemia may exert its malaria protective effect by acting as a major genetic modifier in controlling levels of erythrocytic ATP.

Aside from the effect of thalassemia on red cell ATP levels, and isolated instances of other major genetic modifiers (Loos et al., 1965; Brewer, 1965a), little is known about the genetic control of ATP levels. Analyses of covariance in both Negro and Caucasian sibships (Tables II and III), and the lack of a correlation between spouses (Table 4), suggest that levels of ATP are under at least partial genetic control. Additional evidence along these lines is the relative constancy of ATP levels in erythrocytes of a given individual over a period of years (Brewer and Powell, 1965). The mechanisms of this genetic control are not known with certainty; a priori one might expect that this quantitative characteristic is determined by multifactorial inheritance, since the levels of ATP are probably affected, at least slightly, by a number of enzymes which generate, synthesize, and utilize ATP.

In the present study, significant correlations were not detected between ATP levels and the concentration of serum inorganic phosphorus, the activity in hemolysates of several enzymes, or the electrophoretic type of several additional enzymes from red cells. Either these factors do not influence ATP levels in red cells, or the effect of any one is too slight to detect in the sample size employed.

In view of the effect of thalassemia on levels of ATP, it is of interest that the two other major systems hypothesized to have protective effects against malaria, sickle hemoglobin and G-6-PD deficiency (Beet, 1946; Motulsky, 1960), do not influence ATP levels. Their protective influence is apparently mediated through other mechanisms.

\section{ACKNOWLEDGMENT}

The author gratefully acknowledges the assistance of Dr. Charles Sing of the Department of Human Genetics, University of Michigan, in carrying out the covariance analysis.

\section{REFERENCES}

Allison, A. C. (1954). Brit. Med. J. $1: 290$.

Beet, E. A. (1946). E. African Med.J. 23: 75.

Brewer, G. J., Tarlov, A. R., and Alving, A. S. (1960). Bull. World Health Organ. 22: 622.

Brewer, G. J., Tarlov, A. R., and Alving, A. S. (1962). J. Am. Med. Assoc. 180: 386.

$\mathrm{C}$ 
Brewer, G. J., Powell, R. D., Swanson, S. H. and Alving, A. S. (1964)., J. Lab. Clin. Med. 64: 601. Brewer, G. J. (1965a). Biochem. Biophys. Res. Commun. 18: 430.

Brewer, G. J. (1965b). J. Lab. Clin. Med. 66: 858.

Brewer, G. J., and Powell, R. D. (1965). Proc. Nat. Acad. Sci. 54: 741.

Brewer, G. J., and Powell, R. D. (1966). J. Lab. Clin. Med. 67: 726.

Brewer, G., Siniscalco, M., Lenzarrini, L., and Latte, B. (In preparation).

Fildes, R., and Harris, H. (1966). Nature 209: 5020.

Fisher, R. A. (1958). Statistical Methods for Research Workers. Hafner, New York.

Fiske, C. H., and Subbarow, Y. (1925), J. Biol. Chem. 66: 375.

Glock, G. E., and McLean, P. (1953). Biochem. J. 55: 400.

Hopkinson, D., Spencer, N., and Harris, H. (1964). Am. J. Human Genet. 16: 141.

Hurt, G. A., and Chanutin, A. (1964). J. Lab. Clin. Med. 64: 675.

Kornberg, A. (1950). J. Biol. Chem. 182: 779.

Long, W. K., and Carson, P. E. (1961). Biochem. Biophys. Res. Commun. 5: 394.

Loos, J. A., Zurcher, C., and Prins, H. K. (1965). Presented at the IV International Symposium on Erythrocytes, p. 260.

Motulsky, A. G. (1960). Human Biol. 32: 28.

Powell, R. D., and DeGowin, R. L. (1965). Nature 205: 507.

Spencer, N., Hopkinson, D., and Harris, H. (1964). Nature 204: 742.

Steel, R. G. D., Torrie, J. H. (1960). Principles and Procedures of Statistics. McGraw-Hill Book Company, Inc., New York.

Tanaka, K. R., Valentine, W. N., and Miwa, S. (1962). Blood 19: 267.

Zinkham, W. H., and Lenhard, R. E. (1959). J. Pediat. 55: 319: 